\title{
A Prognosis of the Interplay Between Customer Relationship Management and Loyalty in the Real Estate Industry of Lagos State
}

\author{
ELEBODA, Sunday Samuel \\ Department of Administration and Management, \\ College of Business and Social Sciences, Crawford University, Faith City, Igbesa, Ogun State, Nigeria \\ EREKOSIMA, Mercy Okorite \\ Department of Business Administration, Postgraduate School, Crawford University, Faith City, \\ Igbesa, Ogun State, Nigeria
}

\begin{abstract}
The traditional method of managing properties in Nigerian urban areas demonstrates a relationship of adversity between the tenant and the landlord/landlady/agent. This traditional way of managing properties by focusing on the tenant as a source of funds to the landlord or property manager rather than see the tenants as those that should be nurtured and cherished, will not sustain the industry in the long run. Hence, this study examined the impact of customer relationship management on customer loyalty in the real estate industry of Eti-Osa local government area of Lagos state. The study population consisted of the tenants who live within the LGA by occupying one property or the other for the purpose of residency and/or commercial activities. A sample of two hundred and twenty-four (224) was chosen using multi-stage sampling technique, and data were collected through the use of questionnaire. One hundred and seventy-three (173) (77\%) of the questionnaire copies distributed were returned. Analyses were done using some descriptive statistics and regression. The study found that CRM had significant effect on customer loyalty: $\mathrm{RIN}\left(\beta_{1}=0.158 ; \mathrm{t}=1.973 ; \mathrm{P}<0.05\right), \operatorname{RoV}\left(\beta_{2}=0.219 ; \mathrm{t}=1.199 ; \mathrm{P}<0.05\right), \operatorname{FRD}\left(\beta_{1}=0.208 ; \mathrm{t}=1.853\right.$; $\mathrm{P}<0.05)$, The study recommends that property agents should reach out to potential and existing customers through CRM activities especially in the areas of making relevant information available as at when necessary, maintaining friendly disposition with clients, and paying tenants friendly visits at intervals.
\end{abstract}

Keywords: Real Estate, Customer Relationship Management, Customer Loyalty, Property, Agency

DOI: $10.7176 / \mathrm{JMCR} / 69-02$

Publication date:July $31^{\text {st }} 2020$

\section{Introduction}

It would be no exaggeration to say that majority of the people who live in urban areas in Nigeria live in rented or leased apartments. In the same vein, more than $70 \%$ of commercial or business premises are either rented or leased (NBS, 2017). This situation is most pronounced in the major capital cities such as Lagos, Port Harcourt, Kano, Ibadan, Abuja, to mention a few. Interestingly however, right from time immemorial, the traditional method of managing properties in the Nigerian urban areas where property management and real estate thrive most, demonstrates a relationship of adversity between the tenant and the landlord/landlady.

Before the 20th century, it was not uncommon to find the interest of property managers solely fixated on rent and profit maximization with a near-total lack of customer-centricity (Sayce, Sundberg, Parnell, \& Cowling, 2009). And whenever this interest is threatened, the common practice was to resort to legal means to resolve disputes between the parties involved. As suggested by Edington (1997, p. xii) such approach to property management "gives no glimpse of the notion that if a supplier (the landlord) is receiving substantial sums (rents) from the customer (tenant), then the customer has the right to receive exemplary service." In the opinion of Edington (1997), this traditional way of managing properties which focuses on the tenant as a source of "upwardly mobile income" to the landlord or property manager rather than see the tenant as those that should be mobile and their "custom earned', will not sustain the industry in the long run.

The Nigerian real estate industry has fared very little in the area of managing customer relationships. There is still a great reliance on the traditional method of property management. Even globally, until recently, the real estate industry has not focused enough on customer relationships (Appel-Meulenbroek, 2008; Valley, 2001; Worthington, 2015). However, there has been significant gradual shift towards managing properties and real estates in a manner that is customer-focused and geared towards building long-lasting customer relationships (Palm, 2017).

Being customer-centred and building a robust long-lasting customer relationships requires that a firm deploys a rigorous customer relationship management (CRM) strategies that ensure customer satisfaction and loyalty. Towards this end, many landlords and managing agents acknowledge that describing property occupiers as "customers" rather than "tenants" enables the property manager to develop a partnership that translates into a 
mutually beneficial, and respectful relationship (Goobey, 2006; Kivlehan, 2011).

As opined by Karakostas (2005), customer relationship management is the management approach that seeks to create, develop, and enhance relationships with carefully targeted customers in order to maximize customer value and corporate profitability. Kuo-Chung and Chin (2012) stated that CRM has become an important issue in organizations in order to gain customer loyalty, improve customer satisfaction and retention rates as well as increase profits.

In recent times there has been an increase in the attention given to the perceived relationship between occupier (tenant) satisfaction and the financial performance of property managers, especially in developing countries like Nigeria. This explains why many property investors in Nigeria, particularly in Lagos state, ought to give greater priority to the creation of good tenant-landlord relationships (Oyedokun, Oletubo, \& Adewusi, 2014).

The real estate or commercial property management industry in Lagos state, and more specifically in Eti-Osa Local government area of the state, is known to be volatile being one of the nerve-centres of the nation's real estate commercial activities. Eti-Osa LGA houses many operators in the real estate business including those that are corporate as well as individuals. These include corporate estate agents such as Jide Taiwo \& Co, and those individuals that are popularly called Care-takers. Whatever the nomenclature, these operators continue to face challenges and are currently facing their toughest competition ever (Shemwell, 1998) arising from the growing needs of the industry in addition to the leaner pockets of the average customer or property-occupier or tenant.

Most companies are aiming for good customer relationship which means better service to the customer, thereby making the customer to remain loyal. Customer relationship management supports real estate companies to retain customers and maintain good relationships with them in order to gain their loyalty and long term commitment, create long term competitive advantage, improve customer relations, and enhance customer experience. Despite this, most real estate companies in Eti-Osa Local Government Area of Lagos State do not appear to implement effective CRM systems most probably due to reasons such as lack of knowledge about CRM and/or lack of financial resources to implement same, inexperienced staff to manage customer information, political interference and poor regulation of the sector. A couple of scholars (Ata \& Toker, 2012; Sudhakar \& Sudharani, 2012, Chuchuen \& Chanvarasuth, 2011,) state that organizations that have adopted CRM systems as a corporate strategy are expected to grow at a faster pace than those firms who are non-adopters of CRM within the same industries.

Also, generally in Nigeria, and specifically in Lagos state, resources are devoted more to managing assets rather than managing customers' relationships. The method of information storage in majority of the companies is poor, such that CRM strategies are either non-existent or badly managed. It is against the background of the issues raised above that this study sought to investigate the effect of customer relationship management on loyalty in the real estate industry of Eti-Osa local government area of Lagos state.

\section{Literature Review}

\subsection{Study Area}

Eti-Osa local government area is one of the twenty local governments in Lagos state. It is administered by the state as four distinct local council development areas (LCDA) namely: Ikoyi-Obalende, Eti-Osa East, Eti-Osa West, and Iru Victoria Island (Eti-Osa LGA, 2018). As shown in figure 1 below, the local government covers a wide area in terms of landscape and many important communities of Lagos state. 


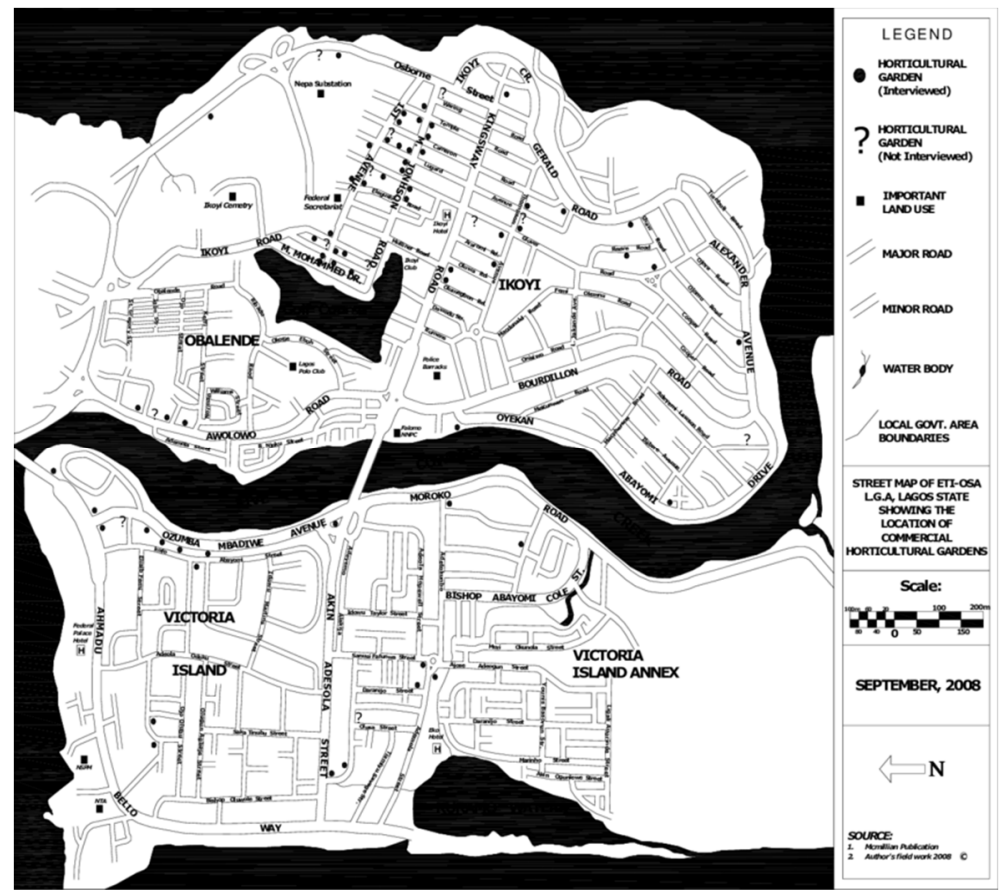

Figure 1: A street map of Eti-Osa local government area of Lagos state

Source: Abegunde (2009), Commercial practice in Nigeria: Its social-spatial effects in Lagos city.

\subsection{Conceptual Review}

\subsection{1: Customer Relationship Management (CRM) as a Concept}

The Customer relationship management (CRM) concept refers to a business strategy focused on the customer, to the extensive process that integrates sales, marketing and clients' service to create value for both the company and customers. CRM is a strategy based on developing relationships with clients. In recent years, CRM has flourished and now can be considered necessary for any company that wants to succeed. It is focused on retaining customers by collecting data from any contact with them either by phone, e-mail, internet, etc. The company can use this information for specific purposes such as marketing, sales and after sales services. The underlying philosophy is that everyone in the company should focus on the customer.

One of the first references to CRM is that it is a marketing oriented approach towards creating strong stable relationship with individual or specific customers (Jackson, 1985).

Gordon (1988) defined CRM as a continuous process of creating value for specific customers and benefits from the ongoing and long term processes both for the business and the client. In addition, Gordon admits that the long-term creation of value for customers is more important than simple transactions, and therefore tries to build a chain of relations as between the firm and its clients as well as between businesses and their main partners. In a study Parvatiyar and Sheth (2000) concluded that customer relationship management is a strategic process integrated and comprehensive that focuses on gaining and maintaining selected clients in order to create maximum value for the business and for the client itself. According to a study by Smith (2002) CRM was defined as a type of business strategy, which is a combination of technology and customer life cycle management in the most efficient manner.

The ultimate goal of companies is the creation of consumer satisfaction using CRM technologies and philosophy. Organizations are evermore setting strategies to determine and make sure customer retention, and charging their employees to be more customer-focused and service-oriented (Mohsan et al., 2011). The most important goal that companies follow up is to maintain customer loyal to the firm so they are more focused on customer centric approach in their organizational and marketing strategies (Jain \& Singh, 2002). Bowen and Chen (2001) said that having satisfied customers is not sufficient, there has to be really satisfied customers. This is because customer satisfaction has to lead to customer loyalty.

\subsubsection{Concept of Customer Loyalty}

The term customer loyalty is used to describe the behaviour of repeat customers, as well as those who offer good ratings, reviews, or testimonials about a firm or its product(s). Some customers do a particular company a great service by offering favourable word-of-mouth publicity regarding a product, telling friends and family, and adding them to the number of loyal customers (Oliver; 2007). Customer loyalty includes much more than retention; it is a process, a program, or a group of programs geared toward keeping a client happy so he or she will provide more business. A company can help build loyalty in some cases by offering a quality product with a firm guarantee. 
Others provide free offers, coupons, low interest rates on financing, high value trade-ins, extended warranties, rebates, and other rewards and incentive programs. The ultimate goal is to create happy customers who will return to purchase again and again, and persuade others to use that company's products or services. This ultimately leads to profitability and happy stakeholders (Girishanker; 2000).

Customer loyalty may involve a one-time program or incentive, or an on-going group of programs to entice consumers. Buy-one-get-one-free programs are very popular, as are purchases that come with rebates or free gifts. Another good incentive is offering a risk free trial period for a product or service. Also known as brand name loyalty, these types of incentives are meant to ensure that customers will return, not only to buy the same product again and again, but also to try other products or services offered by the company. Excellent customer service or relationship management is key (Oliver; 2007). If a client has a problem, the company should do whatever it takes to make things right. If a product is faulty, it should be replaced or the customer's money should be refunded. This should be standard procedure for any reputable business, but those who wish to develop customer loyalty on a large-scale basis may also go above and beyond the standard. They may offer even more by way of free gifts or discounts to appease the customer.

\section{3: Theoretical Framework}

\subsubsection{Theories/Models of CRM}

i. Operational CRM

According Dyche (2002, p.13), "an operational CRM is also known as front office CRM which includes points of direct contact with the customer, which are also known as touch points. A touch point may be an interior touch (eg a call telephone line support for the customers of the company), or a contact from outside (eg a sales call or a face to face promotion email to customers). In other words, an operational CRM is used to capture customer data. An operational CRM also enables and streamlines communications to and from customers, but it does not mean necessarily optimization of service. Just because a bank client controls his/her balance on a website, does not finally decide that he/she prefers not to carry out the transaction of his/her branch.

Operational CRM include:

- Operating systems: the application of systems (e.g. sale, resale, rental management systems) that support customer interactions with Front Office processes (processes visible to customers) and back office processes (processes not directly visible to customers).

- Databases: consolidated and dependent databases (e.g. client, customer interaction, sales) that support a variety of system applications. A key aspect of CRM is to ensure that both clients and the company have a particular view of each other. It is important that the different departments share information for consumers. Therefore, in the functional structure of CRM, consumer information is stored in the database to facilitate business transactions.

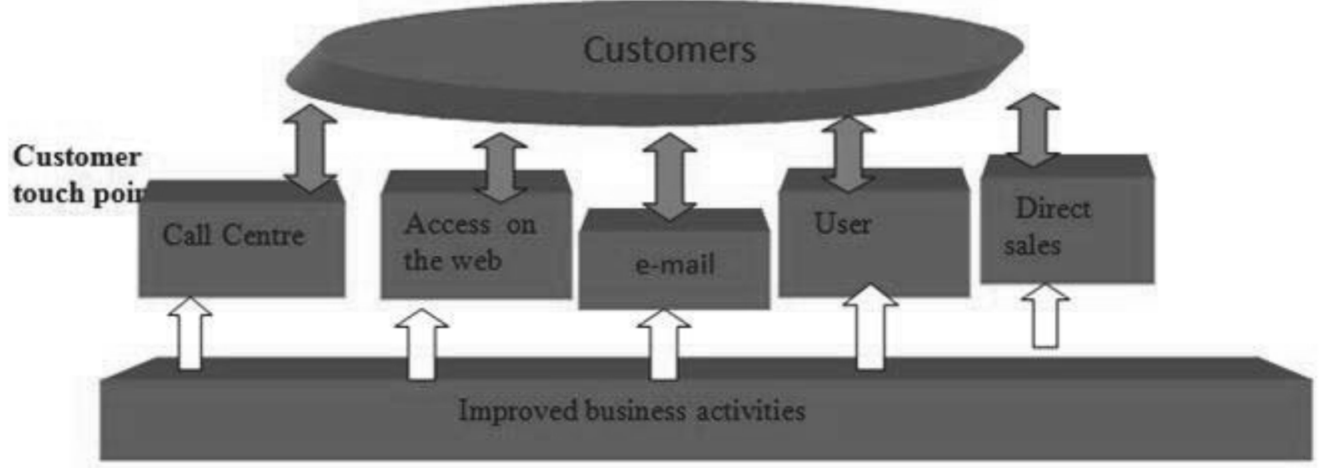

ii Analytical CRM

Figure 1: Operational CRM: Touching the Customer (Resource: Dyche', 2002, p.13)

An analytical CRM is also known as a back office CRM. It involves understanding the customer activities that occurred in the front office. Analytical CRM requires technology (to compile and process the huge files of customers' data to facilitate analysis) and new business processes (proportioned practices dealing with customers to increase loyalty and profitability). Under pressure from analysts and industry experts, today most vendors of CRM are either creating analytical capabilities CRM or partnerships with retailers of intelligence business (BI business intelligence) to incorporate analysis into their offerings (Dyche, 2002). 


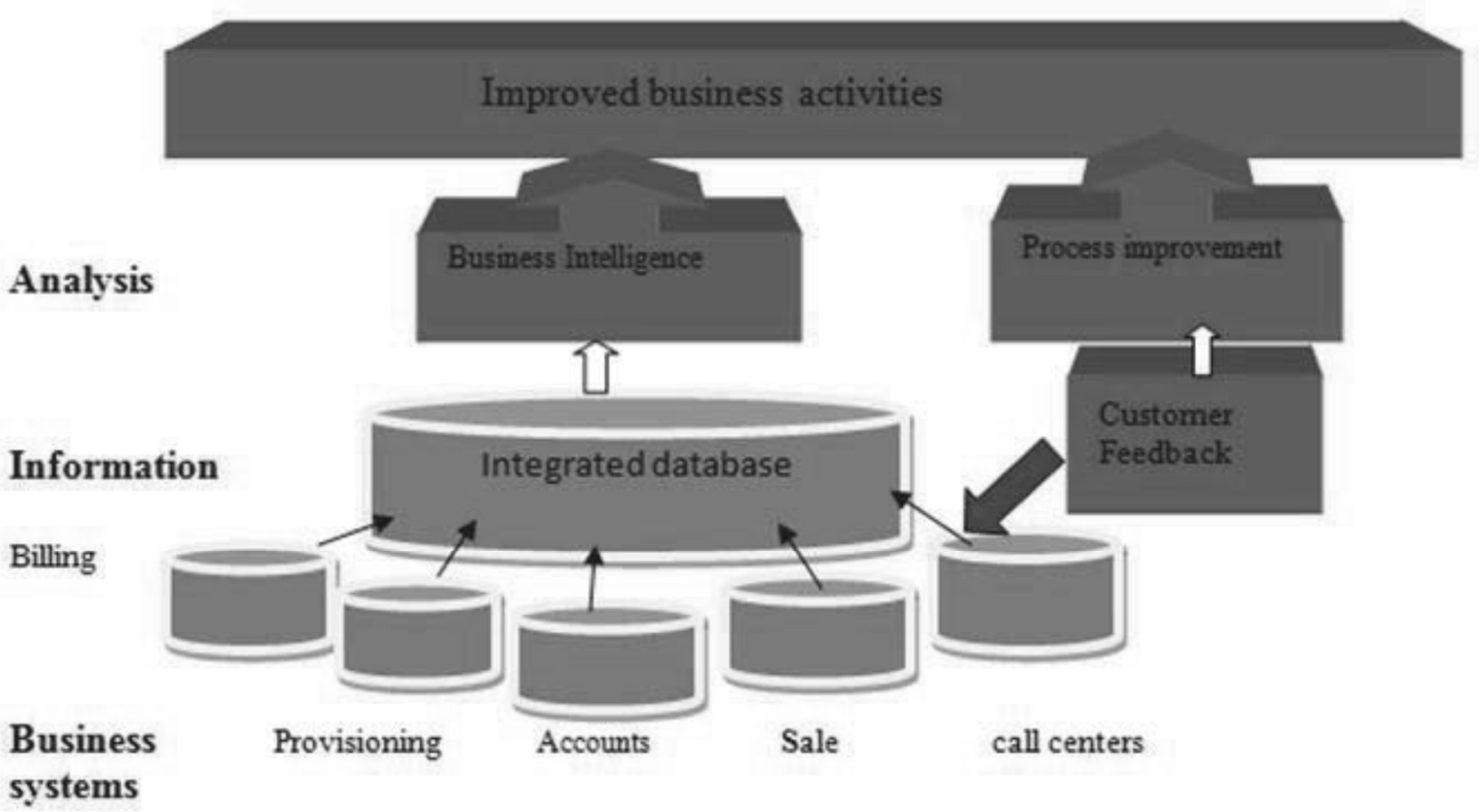

Figure 2: Analytical CRM: Understanding the Customer (Source: Dyche, 2002)

Similarly, Adebanjo (2003) describes an analytical CRM as a tool used mainly for the building of data warehouse, improving relationships, and analyzing customers' data.

\section{iii Collaborative CRM}

According to the provisions of Search CRM (2007), "a collaborative CRM is an approach whereby different departments of a company such as sales, technical support and marketing etc., share any information they collect from interactions with their customers. For example, customer feedback gathered by a session of technical support staff can inform marketing staff about products and services that may be interesting to the customer. The aim of this cooperation is to improve the quality of customer service in order to increase customer satisfaction and loyalty. "Minna and Aino (2005) and Adebanjo (2003) explained that:" a system of collaborative CRM is mainly used for construction online communities, the development of business-to-business transactions, and personalization of services. "

\section{iv. Strategic CRM}

Based on the ideas of Buttle (2009, p.4), strategic CRM is focused on developing a culture of customer-centric business within an organization. This Culture is committed to gaining and maintaining customers by creating and disseminating better value than competitors. Also, according to such culture, the resources are allocated where they will enhance customer value, the system of rewards to encourage behavior of employees that increase customers' satisfaction and retention. In this way, the heroes of business will be them that distribute better value or service to customers.

As a logical result of the appearance of the concept ' Relationship Marketing"' since the 1920s, the concept" Customer Relationship Management' (CRM) has been brought to attention in late nineties, especially among the academics and partitions. The new concept has directed attention towards various vital aspects, including the necessity of direct relationship between customers and markets, the important of keeping current customer, as well as the inevitability building long-term relationships with customers instead of the customer-oriented transaction method in order to augment the profitable of the institutions, especially in today's increasingly competitive economy (Ismail \& et. al, 2007, p.16; Jayachandran \& et. al,., 2005). Therefore, the organization has directed their attention to CRM and abundant investing in the necessary infrastructure, with special concern the great advance in information technology (Ismail \& et al., 2007; Jayachadran \& et. al 2005,). Some considered, therefore, that improving the performance could be achieves through directing more attention to CRM (Malmi et. al, 2004,). Now, CMR is considered one of the most important targets in about $60 \%$ of the projects around the world. Great advance in technology helped in better dividing of the market territories, enhancing communications with customers, providing an environment rich with information so as to contribute in improving efficient strategies to deal with customers.

\subsection{Empirical Review}

In a recent study of the satisfaction of store managers in Shopping Centres in Nigeria by Oyedokun, Oletubo, and 
Adewusi (2014), which looked at the importance and performance of aspects of shopping centre management, it was discovered that the aspect of service delivery that matters most to the respondents was the timeliness of delivery on promises made, which had a Mean Rating of 4.3 / 5 for importance. In addition to this, the study also found that the following aspects of satisfaction and CRM were important to tenants: Having a concerned and caring attitude, Communication and contact with property manager, Time taken to respond to tenant's complaints, Timeliness of Maintenance and Repair Works, Capability and Competency of management, Letting you know when things will be done, Transparency and Accountability in Service Charge Administration, and Timing / Schedule of Rent Payment. Respondents also indicated that they were satisfied in respect of the following: Friendliness of staff and Management, Having a concerned and caring attitude, and Communication and contact with property manager.

Azza (2014) examined the effects of CRM implementation on organizations' performance and on their competitive advantage. The study found that there was positive relationship between CRM implementation and banks performance and their competitive advantage, which led to the conclusion that process and information technology have been the driving forces of CRM success.

Christian, Cho, et.al. (2013) investigated the impact of customer relationship management on customer satisfaction and loyalty. The study was performed at a departmental store in Tehran, Iran. The study employed quantitative approach, and was based on 300 respondents. The main findings of the study was that behavior of the employees is significantly related and contributed to customer loyalty compared to other elements of CRM i.e, interaction management, relationship management and service quality.

Kocoglue (2012), in his study of customer relationship management and customer loyalty in the banking industry, conducted on a sample of 350 staff employed in all the branches of T.C. Ziraat Bank in Denizili, concluded that all elements of CRM (i,e customer database, learning customer needs and complaints, and providing solutions peculiar to customers) were positively correlated with customer loyalty.

According to the research by Bhattachacharya (2011), CRM is implemented in an organization to reduce cost and increase company performance, which means profitability result through customer satisfaction and loyalty. Indeed in a successful CRM implementation, data are collected from internal and external sources such as sales department, customer service, marketing, after sales services, and procurement, this is crucial in obtaining a holistic view of each customer requirement in real times systems. This information will aid employees to make fast accurate decision when dealing with the customers in different areas and touch points. The finding of this study shows that the customer perception and treatment given to each customer individual able to assist in solving many customers problems. Thus, customer satisfaction and loyalty would be achieved through a successful CRM implementation. Therefore, organization should discover different requirements of the customers and adjust their policies according to their needs which increase the firm's competitiveness.

\subsubsection{Critical Success Factors In Customer Relationship Management Implementation Strategy}

Implementing a successful customer relationship management strategy in strategic management of internal market of a company that has the above benefits may depend on the following key factors:

i. Training company employees: Company employees should be trained in the field of interaction and connection with the customers to be able to communicate with customers effectively and also have the ability to use new technologies.

ii. Reviewing processes and designing new processes: firms without well-designed and logical processes cannot achieve their goals. Companies should define their business needs and goals, and related customer relationship management processes should be improved and expanded to achieve these needs. Business Process Re-engineering or BPR is one of the effective tools in this section (Swift; 2002).

iii. Applying new technologies: Using customer relationship management requires changes in the infrastructure of the organization and deployment of new technologies like new business rules, databases, information technology and so on. These changes will lead to an effective and useful development.

\section{Methodology}

This study adopted the descriptive survey method by obtaining cross-sectional data from respondents through the use of questionnaire to evaluate the effect of customer relationship management on customer satisfaction, and customer loyalty in the real estate sector. The choice of this research design was due to the fact that data were collected at a particular point in time across the study objects. Also, since the research objectives include an investigation of the effects of one variable on another, and because there is availability of prior theoretical evidences to formulate hypotheses, the descriptive survey was considered most appropriate for the study and was therefore adopted.

The data for the study were obtained through the use of questionnaire. The questionnaire consists of four sections: A, B, and C. While section A contained structured questions about the demographic variables of the respondents, section $\mathrm{B}$ contained questions on $\mathrm{CRM}$ and its component parts, and section $\mathrm{C}$ asked questions relating to customer loyalty. The response categories were structured along Likert scale as well as other categories 
based on the nature of the questions involved.

The population of the study consisted of the tenants who live within Eti-Osa Local Government Area of Lagos State, who were occupiers of one property or the other for the purpose of residency and/or commercial activities. It also includes both private and corporate tenants within the local government. The actual numbers of these different categories of tenants, which run into millions, are indeterminate as no accurate data in that respect currently exists.

Since the actual population of the study was unknown as stated above, the sample size for the study was derived based on the formula suggested by Cochran (1963), cited in Israel (1992), and Daniel \& Terrel (2006) for obtaining sample size for populations that are large and/or indeterminate thus:

$\mathrm{n}=\frac{\mathrm{Z}^{2} \mathrm{pq}}{\mathrm{e}^{2}}$

Where:

$\mathrm{n}=$ sample size

$\mathrm{Z}=$ level of confidence desired

$\mathrm{e}=$ the sampling error to be tolerated between the true value and the estimated value (desired level of precision)

$\mathrm{p}=$ the estimated proportion of an attribute that is present in the population (or degree of variability), and

$$
q=1-p
$$

For this study,

$(Z)=95 \%$ (i.e. $p<0.05)$ in order to reduce the risk of selecting a sample size that does not reflect the true population mean.

(e) $= \pm 6 \%(0.06)$ so as to ensure that the margin of error is minimized.

$(p)=0.3(30 \%)$ based on the belief that the study population is homogenous with regard to the attributes of interest (i.e. CRM, satisfaction, and loyalty) which are normally distributed.

(q) $=1-0.3=07$

Substituting these in equation (1) above therefore,

$\mathrm{n}=\frac{(1.96)^{2}(0.3 \times 0.7)}{(0.06)^{2}}$

$\mathrm{n}=3.8416 \times 0.21$

0.0036

$\mathrm{n}=0.806736$

0.0036

$\mathrm{n}=224.09$

Approx. $=224$ respondents

Based on the calculation above, a total of two hundred and twenty-four (224) tenants were sampled using multi-stage sampling procedure that incorporates purposive, quota and accidental sampling methods as follows:

First, the local government was divided along the four distinct local council development areas (LCDA) namely: Ikoyi-Obalende, Eti-Osa East, Eti-Osa West, and Iru Victoria Island, using cluster sampling technique. Thereafter, the quota sampling technique was used to select 56 respondents from each of the LCDA which brought the total number of respondents sampled to two hundred and twenty-four (224). Then, purposive and convenience sampling methods were employed to choose the corporate and individual tenants in order to ensure adequate coverage of the sampling frame. This sample size and procedure was regarded as adequate for the study such that the outcome of the data analysis will be generalizable.

In order to ensure the validity of the study instrument, a pilot study was conducted by distributing the instrument to a handful of twenty (20) of the targeted respondents, who were randomly selected as pilot samples. The returned questionnaire copies were analysed to determine the internal consistency of the research questions and variables by calculating the Cronbach alpha coefficients. As shown in table 3.1 below, the Cronbach alpha of 0.705 indicate that the instrument was considered reliable.

Table 3.1: Reliability Statistics

\begin{tabular}{|r|r|c|}
\hline Cronbach's Alpha & Cronbach's Alpha Based on Standardized Items & N of Items \\
\hline .709 & .705 & 27 \\
\hline
\end{tabular}

\subsection{Model Specification}

The study adopted multiple regression as the statistical method to test the effect of customer relationship management on customer loyalty. The Model Specification is as follow:

$\mathrm{Y}=\mathrm{f}(\mathrm{X})$

Where:

$\mathrm{Y}=$ Dependent variable

$\mathrm{X}=$ Independent variable

Therefore, 
$\mathrm{Y}=$ Customer Loyalty (CUSLOY)

$\mathrm{X}=$ Customer Relationship Management (CRM)

But: $\mathrm{X}=\mathrm{x}_{1}, \mathrm{x}_{2}, \mathrm{X}_{3}$,

Where;

$\mathrm{x}_{1}=$ Relevant Information (RIN)

$\mathrm{x}_{2}=$ Regularity of Visitation $(\mathrm{RoV})$

$\mathrm{x}_{3}=$ Financial Matters (FIM)

$\mathrm{x}_{4}=$ Friendly Disposition (FRD)

Therefore;

CUSLOY $=\beta_{0}+\beta_{1} \mathrm{x}_{1}+\beta_{2} \mathrm{x}_{2}+\beta_{3} \mathrm{x}_{3}+\beta_{4} \mathrm{x}_{4}+e$

And:

CUSLOY $=\beta_{0}+\beta_{1}(\mathrm{RIN})+\beta_{2}(\mathrm{RoV})+\beta_{3}(\mathrm{FIM})+\beta_{4}(\mathrm{FRD})+\mathrm{e}$

Where:

$\beta_{0}=$ intercept

$\beta_{1--} \beta_{4}=$ slope

$\mathrm{e}=$ error term

\section{Results and Discussion of Findings}

A total of two hundred and twenty-four (224) copies of the questionnaire were distributed to both corporate and private tenants of real estate properties in Eti-Osa LGA of Lagos state, out of which one hundred and seventythree (173), representing about 77\%, were returned and found useable. The returned questionnaire copies were analyzed as presented below:

4.2.1: Frequency Tables in Respect of the Demographic Variables of the Respondents

\begin{tabular}{|l|l|r|r|r|r|}
\hline \multicolumn{2}{|c|}{ Table 4.1: Type of Accommodation } \\
\hline \multicolumn{1}{|c|}{ Valid } & Frequency & \multicolumn{1}{c|}{ Percent } & Valid Percent & Cumulative Percent \\
\cline { 2 - 6 } & Self-contained & 109 & 63.0 & 63.0 & 63.0 \\
\cline { 2 - 6 } & Room-and-Palour & 22 & 12.7 & 12.7 & 75.7 \\
\cline { 2 - 6 } & Single Room & 21 & 12.1 & 12.1 & 87.9 \\
\cline { 2 - 6 } & Duplex & 13 & 7.5 & 7.5 & 95.4 \\
\cline { 2 - 6 } & Others & 5 & 2.9 & 2.9 & 98.3 \\
\cline { 2 - 6 } & 99 & 1 & .6 & 1.6 & 100.0 \\
\cline { 2 - 6 } & Total & 2 & 1.2 & 100.0 & \\
\hline
\end{tabular}

Source: Field Survey, 2019

As presented in table 4.1 above, 109 (63\% of the tenants sampled were occupying flats of various descriptions including 1, 2, 3, or 4 bedrooms, 22 (12.7\%) were occupying self-contained apartments, 21 (12.1\%) were living in room-and-parlour apartments, $13(7.5 \%)$ occupied single rooms, $5(2.9 \%)$ were occupying duplexes, while only $1(0.6 \%)$ indicated living in 'other' types of apartment. Meanwhile, $2(1.2 \%)$ of the responses in this regard were invalid because respondents did not answer the related question correctly.

\begin{tabular}{|c|c|c|c|c|c|}
\hline & & Frequency & Percent & Valid Percent & Cumulative Percent \\
\hline \multirow[t]{4}{*}{ Valid } & Individual & 96 & 55.5 & 59.3 & 59.3 \\
\hline & Corporate/Company & 41 & 23.7 & 25.3 & 84.6 \\
\hline & Can't really say & 25 & 14.5 & 15.4 & 100.0 \\
\hline & Total & 162 & 93.6 & 100.0 & \\
\hline Invalid & 99 & 11 & 6.4 & & \\
\hline \multicolumn{2}{|l|}{ Total } & 173 & 100.0 & & \\
\hline
\end{tabular}

Source: Field Survey, 2019

Table 4.2 above presents the outcome of the analysis in respect of how the participants would describe the 'agent' through whom they obtained their apartments. It shows that $96(55.5 \%)$ of the respondents would describe the agent as individual, $41(23.7 \%)$ referred to them as corporate/company, while $25(14.5 \%)$ couldn't really describe the identity of the agent. Meanwhile, $11(6.4 \%)$ of the responses (probably majority of those who acquired their apartments directly from owners) in this regard were invalid because respondents did not answer the related question. 


\begin{tabular}{|l|l|r|r|r|r|}
\hline \multicolumn{2}{|c|}{ Table 4.3: Duration of Securing Accommodation through Current Agent } \\
\hline \multicolumn{1}{|c|}{} & Frequency & Percent & Valid Percent & $\begin{array}{c}\text { Cumulative } \\
\text { Percent }\end{array}$ \\
\hline Valid & Less than 6 months ago & 17 & 9.8 & 10.9 & 10.9 \\
\cline { 2 - 6 } & Between 6 and 12 months ago & 24 & 13.9 & 15.4 & 26.3 \\
\cline { 2 - 6 } & Between 1 and 5 Years ago & 91 & 52.6 & 58.3 & 84.6 \\
\cline { 2 - 6 } & Between 6 and 10 Years ago & 8 & 4.6 & 5.1 & 89.7 \\
\cline { 2 - 6 } & Between 11 and 15 Years ago & 6 & 3.5 & 3.8 & 93.6 \\
\cline { 2 - 6 } & More than 15 Years ago & 8 & 4.6 & 5.1 & 98.7 \\
\cline { 2 - 6 } & Can't Remember & 2 & 1.2 & 1.3 & 100.0 \\
\cline { 2 - 6 } & Total & 156 & 90.2 & 100.0 & \\
\hline Invalid & 99 & 173 & 100.0 & & \\
\hline Total & & & 9.8 & & \\
\hline
\end{tabular}

Source: Field Survey, 2019

Table 4.3 above presents the outcome of the quest to know the duration within which each respondent has been securing accommodation through their current agent. The table shows that $17(9.8 \%)$ confirmed that they have secured accommodation with the help of the agent for less than 6 months, 24 (13.9\%) claimed between 6 and 12 months ago, $91(52.6 \%)$ stated for between 1 and 5 years ago, $8(4.6 \%)$ had been securing accommodation for between 6 and 10 years ago, while $6(3.5 \%)$ had been securing accommodation for between 11 and 15 years ago, $8(4.6 \%)$ had been securing accommodation for more than 15 years ago, while $2(1.2 \%)$ cannot remember for how long. Meanwhile, $17(9.8 \%)$ of the responses in this regard were invalid because respondents did not answer the related question correctly.

\begin{tabular}{|c|c|c|c|c|c|}
\hline & & Frequency & Percent & Valid Percent & Cumulative Percent \\
\hline \multirow[t]{7}{*}{ Valid } & Less than 1 Year ago & 32 & 18.5 & 18.5 & 18.5 \\
\hline & Between 1 and 3 Years ago & 48 & 27.7 & 27.7 & 46.2 \\
\hline & Between 4 and 6 Years ago & 76 & 43.9 & 43.9 & 90.2 \\
\hline & Between 7 and 10 Years ago & 11 & 6.4 & 6.4 & 96.5 \\
\hline & More than 10 Years ago & 5 & 2.9 & 2.9 & 99.4 \\
\hline & Can't Remember & 1 & .6 & .6 & 100.0 \\
\hline & Total & 173 & 100.0 & 100.0 & \\
\hline
\end{tabular}

Source: Field Survey, 2019

Table 4.4 above presents the outcome of the quest to know how long respondents have been occupying the apartment. The table shows that $32(18.5 \%)$ confirmed that they have secured the apartment for less than 1 year, $48(27.7 \%)$ claimed between 1 and 3 years ago, $76(43.9 \%)$ for between 4 and 6 years ago, $11(6.4 \%)$ had been occupying the apartment for between 7 and 10 years ago, $5(2.9 \%)$ had been for more than 10 years ago, while only $1(0.6 \%)$ cannot remember for how long.

\subsection{Test of Hypothesis}

The study objective was hypothesized and tested with the model specified earlier. The results are presented in the tables below:

\begin{tabular}{|l|c|r|r|r|}
\hline Table 4.5a: Model Summary \\
\hline Model & $\mathrm{R}$ & R Square & Adjusted R Square & Std. Error of the Estimate \\
\hline 1 & $.599^{\mathrm{a}}$ & .349 & .327 & 5.45332 \\
\hline
\end{tabular}

a. Predictors: (Constant), FRD, RIN, RoV, FIM

Source: Author's Computation, 2019

\begin{tabular}{|c|c|c|c|c|c|c|}
\hline \multicolumn{7}{|c|}{ Table 4.5b: ANOVA $^{\mathrm{a}}$} \\
\hline \multicolumn{2}{|c|}{ Model } & Sum of Squares & $\mathrm{df}$ & Mean Square & $\mathrm{F}$ & Sig. \\
\hline \multirow[t]{3}{*}{1} & Regression & 1330.878 & 4 & 332.719 & 11.188 & $.000^{\mathrm{b}}$ \\
\hline & Residual & 4014.722 & 135 & 29.739 & & \\
\hline & Total & 5345.600 & 139 & & & \\
\hline \multicolumn{7}{|c|}{ a. Dependent Variable: CUSLOY } \\
\hline \multicolumn{7}{|c|}{ b. Predictors: (Constant), FRD, RIN, RoV, FIM } \\
\hline
\end{tabular}

Source: Author's Computation, 2019 
Table 4.5c: Coefficients ${ }^{\mathrm{a}}$

\begin{tabular}{|c|c|c|c|c|c|c|c|c|}
\hline \multirow{2}{*}{\multicolumn{2}{|c|}{ Model }} & \multicolumn{2}{|c|}{ Unstandardized Coefficients } & \multirow{2}{*}{$\frac{\text { Standardized Coefficients }}{\text { Beta }}$} & \multirow[b]{2}{*}{$\mathrm{T}$} & \multirow[b]{2}{*}{ Sig. } & \multicolumn{2}{|c|}{ Collinearity Statistics } \\
\hline & & $\mathrm{B}$ & Std. Error & & & & Tolerance & VIF \\
\hline 1 & (Constant) & 6.610 & 2.929 & & 2.257 & .026 & & \\
\hline & RIN & .295 & .150 & .158 & 1.973 & .051 & .872 & 1.147 \\
\hline & RoV & .826 & .415 & .219 & 1.991 & .049 & .461 & 2.168 \\
\hline & FIM & .153 & .198 & .093 & .769 & .443 & .383 & 2.612 \\
\hline & FRD & .366 & 197 & .208 & 1.853 & .006 & .441 & 2.269 \\
\hline
\end{tabular}

a. Dependent Variable: CUSLOY

Source: Author's Computation, 2019

Tables $4.5 \mathrm{a}, 4.5 \mathrm{~b}$, and $4.5 \mathrm{c}$, above present the results of the multiple regression analysis in respect of the interaction between customer satisfaction (CUSLOY) and customer relationship management (CRM: Friendly Disposition (FRD), Relevant Information (RIN), Regularity of Visitation (RoV), and Financial Matters (FIM)). Table 4.5a shows the coefficient of determination $\mathrm{R}^{2}=0.349$ and adjusted $\mathrm{R}^{2}=0.327$ which implies that the changes in customer loyalty are accounted for by Friendly Disposition (FRD), Relevant Information (RIN), Regularity of Visitation (RoV), and Financial Matters (FIM)) combined by about $32.7 \%$, while the remaining $62.3 \%$ are accounted for by other variables not included in the model (otherwise called error term). This also means that the independent variables are not strong predictors of expected change in customer loyalty.

In order not to violate the assumptions underlining the application of multiple regression analysis, multicollinearity diagnostic statistics (variance inflation factors (VIF) and tolerance level) were computed. Table 4.5c shows that VIF for Friendly Disposition, Relevant Information, Regularity of Visitation, and Financial Matters were 1.147, 2.168, and 2.612 and 2.269 respectively. These figures are far lower than the acceptable upper limit of 10; and tolerance values were also higher than the minimum of 0.1 . These indicate that the predictor variables are not strongly correlated; hence there is no problem of multicollinearity.

Table 4.5b shows the $\mathrm{F}$ statistic $(\mathrm{F} 4,135=11.188,(\mathrm{P}<0.01)$ is significant, indicating that the independent variables jointly affect the dependent variable, and the model is fit to predict change in the dependent variable. The relative contributions of each operator independent variable to change in customer loyalty are: RIN $\left(\beta_{1}=\right.$ $0.158 ; \mathrm{t}=1.973 ; \mathrm{P}<0.05), \operatorname{RoV}\left(\beta_{2}=0.219 ; \mathrm{t}=1.199 ; \mathrm{P}<0.05\right), \operatorname{FRD}\left(\beta_{1}=0.208 ; \mathrm{t}=1.853 ; \mathrm{P}<0.05\right)$ which were significant at $5 \%$ level of significance, but the contribution of FIM is not significant $\left(\beta_{2}=0.09 ; \mathrm{t}=0.769 ; \mathrm{P}>0.05\right)$. These imply three of the independent variables have significant impact on customer loyalty while financial matters does not. These show that CRM significantly affects customer loyalty in the real estate industry of Eti-Osa LGA of Lagos State.

\subsection{Conclusions}

The study concludes that three of the independent variables had significant impact on customer loyalty while financial matters did not. This means that real estate agents need to seriously pay attention to the way and manner they treat their tenant-customers when it comes to the issues of finance. In order to further enhance loyalty in the industry, friendly disposition towards client holds the greatest opportunity.

Finally, the study concludes that length of stay in an apartment or a property would not necessarily make a tenant loyal or disloyal. Property occupiers in the real estate sector of Lagos state are not discriminated (in terms of how loyal they are to the agents) based on how long they have rented or leased the property.

\subsection{Recommendations}

Deriving from the findings and conclusions, the study recommends that:

i. Property agents should reach out to potential and existing customers through CRM activities especially in the areas of making relevant information available as at when necessary, maintaining friendly disposition with clients such as allowing them some financial relieves when situations demand, and paying tenants friendly visits at intervals.

ii. Thus, property agents and managers within the industry and the local government should intensify efforts towards developing better customer relationship management practices since the more improved and enhanced the CRM, the better the chances of developing existing customers into loyal ambassadors of the agency and winning potential new customers. Developing a better CRM should be based on training, particularly those who relate directly with corporate or individual clients or tenants which should be developed and adapted consistently to the changing role of CRM in the organization.

iii. Property agencies should also imbibe the spirit of CRM or improve its implementation (if already in place in the organization) in order to increase customer satisfaction. By so doing, customer loyalty will improve with the attendant increase in referrals, patronage, and ultimately profitability. 


\section{REFERENCES}

Abegunde.W.T. (2009). Customer relationship management research (1992-2002). An academic literature review and classification. Marketing Intelligence Planning, 23, 582-605.

Adebanjo, G.J (2003). Customer relationship management and organizational performance. International Journal of Management and Organizational, 4(4), 34-38.

Appel-Meulenbroek, O.I (2008). Expansion, cost reduction, or both? Journal of Marketing, 66, 7-24.

Ata, T.Y \& Toker, W.F (2012). CRM dimensions and firm performance. International Journal of Computer Science and Network Security, 10(12), 84-105.

Azza, E. (2014). The effect of customer relationship management on organizations performance and competitive advantage-effect of process and information technology. International Business and Social Science Research Conference/

Bhattacharya, A. (2011). Preeminent Analysis of Customer Relationship Management (CRM). Int.J.RMT, 1(1), 45-51.

Bowen, D. E., \& Chen, B. (2001). Services marketing and management: Implications for organisational behaviour. Research in Organisational Behaviour, 10, 31-48.

Buttle, F. (2009), Teaching notes: MGSM 985C, Macquarie Graduate School of Management, Macquarie University, North Ryde, NSW 2109, Australia.

Christian, H. R, Cho, C.H, \& Andrea O.D (2013). Balanced score card step by step: maximizing performance and maintaining results. New York. John Wiley and Sons

Chuchuen, S.H \& Chanvarasuth, U.D (2011). Customer Relationship Management: From Strategy to implementation. Journal of Marketing Management, 22(3),135-168.

Daniel G., O.\& Terrel, B. G (2006). The impact of knowledge management on SME growth and profitability: A structural equation modelling study. Africa Journal of Business Management, 4(16), 3417-3432

Dyche, J. (2002). The CRM handbook, Addison-Wesley, 2nd printing.

Edington, C,T (1997). A practical guide to CRM. New York: CMP Books

Girishanker; R. R (2000). E-CRM Web service attributes as determinants of customer satisfaction with retail Web sites. International Journal of Service Industry Management, 13 (5), 432 - 451.

Goobey, E (2006). Understanding customer relationship management (CRM): People, process and technology. Business Process Management Journal, 9(5), 672-688

Gourdin, K (1988). Bringing quality back to commercial travel. Transportation Journal, 27(3), 373-391

Ismail, A., Y., H. (2013). Customer Service and Organizational Growth of Service Enterprise in Somalia Educational Research International, 2(2), 79-86

Israel, D. D (1992). Customer relationship management: Towards a common knowledge of an emerging phenomenon. Industrial Marketing Management, 33(6), 475-489.

Jackson, O. (1985). Consumer perceptions of interpersonal equity and satisfaction in transaction: A field survey approach. Journal of Marketing, 53, 21-35.

Jain, D., \& Singh, S. (2002). Customer lifetime value research in marketing: A review and future directions. Journal of Interactive Marketing, 16(2), 34-46.

Jayachandran, I. D, Johan, J. and Storm, F. (2005). Customer relationship management-case studies of five Swedish companies. Luieal University of Technology.

Karakostas, R.K (2005). Strategic goals of CRM and process goals of organizations. Business Process Management Journal, 12(4), 109-128

Kivlehan, I.G (2011). Customer relationship management implementation. An investigation of a scale's generalizability and its relationship with business performance in a developing country context. International Journal of Commerce and Management, 21(2), 158-191.

Kocoglus, H. I (2012). An empirically based typology of product innovativeness for new financial services: Success and failure scenarios. Journal of Product Innovation Management, 18(5), 324- 342.

Kuo-Chung, D \& Chin, T (2012). Getting the most out of all your customers. Harvard

Malmi, B.R., Jason, H.O, \& Hew, S.S (2004). Quality in Service Sector - A Review. International Journal of Brand Marketing, 7(5), 4-12.

Minna, G.H, \& Aino, F.C (2005). A benchmarking implementation framework for Automotive Organizational Readiness on CRM and Business Performance. International Journal of Computers, 1(2), 106-114.

Mohsan, F., Nawaz, M. M., Khan, M. S., Shaukat, Z., Aslam, N (2011). Impact of Customer Satisfaction on Customer Loyalty and Intentions to Switch: Evidence from Banking Sector of Pakistan, International Journal of Business and Social Science Vol. 2 No. 16.

National Bureau of Statistics (2017). Statistics on the aviation industry. Available at www.nbs.gov.ng Accessed on $18^{\text {th }}$ February, 2020.

Oliver, R. L (2007). Satisfaction: A Behavioural Perspective on the Consumer. New York: McGraw-Hill.

Oyedokun, G.A, Oletubo, A.O \& Adewusi, S.T (2014). CRM software applications and business performance. 
Journal of Database Marketing and Customer Strategy Management, 14 (1), 4-16.

Palm, A.B. (2011). The design of organizations. New York. Harcourt Jovanovich, Inc.

Parvatiyar, A. and Sheth, J. N. (2000), "Conceptual framework of customer Relationship management”, in Sheth, Parvatiyar and Shainesh (Eds), Customer Relationship Management: Emerging Concepts, Tools and Applications, Tata McGraw-Hill, New Delhi, p. 3 - 25.

Sayce, R. I., Sundberg, J. C., Parnell, J. L., \& Cowling, R. C. (2009). the effect of franchising on performance: An examination of residential real estate brokerages. Journal of Business Administration Online, 7(2), 45-62.

Shemwell, D.L (1998). Customer relationship management and firm performance: An empirical study of freight forwarder services. Journal of Marine Science and Technology, 20(1), 64-72.

Smith, R. A. \& Houston, M. J. (1983). Script-based evaluations of satisfaction with services. In L. L. Berry, G. L., Shostack, and G. D. Upah (eds.), Emerging Perspectives on Services Marketing. Chicago, IL: American Marketing Association. 59-62.

Sudhakar, P.D \& Sudharani, R.R (2012). Marketing, business process, and shareholder

Swift R.S (2002). Accelerating customer relationship: using CRM and technologies. NJ: prentice Hal, Jovanovich, Inc.

Valley, R.H (2001). The impact of CRM dimensions on call center performance. International Journal of Computer Science and Network Security, 10(12), 184-195.

Worthington, E.D (2015). Competition and choice in the civil aviation industry. Journal of Consumer Research, $18,36-52$ 